\title{
SKRINING MALARIA DI WILAYAH KERJA PUSKESMAS BANYUASIN KECAMATAN LOANO KABUPATEN PURWOREJO PROPINSI JAWA TENGAH
}

\author{
Marhum Nur Amani, Abdul Kadar, Solikhah \\ Fakultas Kesehatan Masyarakat, Universitas Ahmad dahlan, Yogyakarta
}

\begin{abstract}
Background: Operational Area of Banyuasin Public Health Service in Loano Subdistrict, Purworejo Regency, Middle Java Province, includes in endemic area which still has high rate of malaria disease and increased in this last three years. In 2005 it was founded four persons which positively suffered malaria; in 2006 it was founded 66 persons which positively suffered malaria (API 5,4 per 1000 populations) and increase the case in 2007 by 202 persons which positively suffered malaria. Screening test was necessary as initial filtering test of malaria diseases in operational area of Banyuasin Public Health Service, Loano Subdistrict, Purworejo Regency, Middle Java Province.

Method: This was descriptive research using validity test for measuring the sensitivity and specificity of clinical symptoms of malaria as screening test. Technique of sample taking was conducted by consecutive sampling. Population was all of inhabitants living in operational area of Banyuasin Public Health Service, Loano Subdistrict, Purworejo Regency, Middle Java Province. Sample were the persons having periodical fever symptoms, sharp pain in joints, and nauseous symptoms in last two weeks by the amount of samples were 96 persons.

Result of research: Based on validity calculation of screening test of clinical symptom of malaria, sensitivity and specificity rate of periodic fever symptom (Se:100\%, Sp:100\%), sharp pain on joints (Se:58,3\%, Sp:96,4\%), nausea (Se:100\%, Sp:98,8\%). Combination of symptom periodical fever and nausea have sensitivity and specificity rate of (Se:100\%, Sp:98,8\%), periodical fever and sharp pain on joints (Se:58,3\%, Sp:96,4\%), sharp pain on joints and nausea (Se:58,3\%, Sp:100\%), periodical fever and sharp pain on joints (Se:58,3\%, Sp:100\%).

Conclusion: Sensitivity and specificity of the result of these three combinational symptoms, i.e. periodical fever + sharp pain on joints and nausea have sensitivity of $58,3 \%$ and specificity of $100 \%$. It means that these three combinational symptoms can not be used as screening test of malaria by reason of it has low in sensitivity.
\end{abstract}

Keywords: Screening, Sensitivity, Specificity, Malaria, Banyuasin Public Health Service

\section{PENDAHULUAN}

Malaria ditemukan lebih dari 90 negara atau hampir diseluruh bagian dunia, terutama di negara-negara yang beriklim tropis dan subtropis. Penduduk yang berisiko terkena malaria berjumlah sekitar 2,3 miliar atau $41 \%$ dari jumlah penduduk dunia. Di dunia diperkirakan kasusnya berjumlah sekitar 300-500 juta kasus dan mengakibatkan 1,5-2,7 juta kematian setiap tahun, terutama di negara-negara Benua Afrika ${ }^{1}$. Di Indonesia, dari 576 Kabupaten/Kota, 424 Kabupaten/Kota (73,6\%) merupakan daerah endemis malaria dan sekitar $45 \%$ penduduk Indonesia berisiko tertular malaria. Hasil Survei Kesehatan Rumah Tangga (SKRT) tahun 2001, jumlah kasus malaria diderita oleh sekitar 15 juta orang dengan kematian rata-rata 38 ribu orang pertahun ${ }^{2}$.

Berdasarkan data Departemen Kesehatan $\mathrm{RI}^{2}$ pada tahun 2007 jumlah populasi berisiko terjangkit malaria diperkirakan sebanyak 116 juta orang sementara jumlah kasus malaria klinis yang dilaporkan 1.775 .845 kasus (Annual Malaria Incidence/ $\mathrm{AMI}=15,3$ per 1000 penduduk). Jumlah kasus malaria klinis yang dilaporkan sebanyak 930 ribu diantaranya terjangkau pemeriksaan darah (cakupan pemeriksaan darah $52,4 \%$ ) dan jumlah kasus positif malaria sebanyak 311.790 kasus (Annual Parasite Incidence/API= 2,6 per 1000 penduduk). 
Angka kesakitan malaria di Kabupaten Purworejo selama tiga tahun terakhir memperlihatkan kecenderungan peningkatan kasus setiap tahunnya. Tahun 2005 sebesar 324 orang positif malaria (API 0,42 per 1000 penduduk), tahun 2006 sebesar 421 orang positif malaria (API 0,55 per 1000 penduduk) dan 440 orang positif malaria (API 0,57 per 1000 penduduk) pada tahun $2007^{3}$.

Puskesmas Banyuasin merupakan salah satu puskesmas di Kecamatan Loano Kabupaten Purworejo termasuk daerah endemis yang masih tinggi angka kesakitan malarianya dan terjadi peningkatan dalam 3 tahun terakhir. Tahun 2005 ditemukan 4 orang positif malaria, tahun 2006 ditemukan 66 orang positif malaria (API 5,4 per 1000 penduduk) dan terjadi peningkatan kasus pada tahun 2007 yaitu sebesar 202 orang positif malaria ${ }^{4}$. Skrining malaria merupakan suatu usaha untuk mencari dan menemukan penderita penyakit malaria yang tampak gejala klinis melalui suatu tes/ pemeriksaan, yang secara singkat dan sederhana sehingga dapat memisahkan mereka yang sehat dari mereka yang kemungkinan besar menderita penyakit malaria, yang selanjuthya diproses melalui diagnosis dan pengobatan. Uji skrining diperlukan sebagai uji penyaringan awal penderita penyakit malaria di wilayah kerja Puskesmas Banyuasin.

Fenomena tersebut merupakan latar belakang bagi peneliti untuk melakukan penelitian tentang "Skrining Malaria di Wilayah Kerja Puskesmas Banyuasin Kecamatan Loano Kabupaten Purworejo Propinsi Jawa Tengah".

Alasan peneliti memilih Puskesmas Banyuasin sebagai tempat penelitian karena wilayah kerja Puskesmas Banyuasin merupakan daerah endemis malaria dengan kasus yang tinggi dengan API sebesar 202 kasus per 1000 penduduk pada tahun 2007, dengan tujuan untuk mengetahui validitas gejala klinis malaria yaitu demam periodik, nyeri pada persendian dan mual sebagai uji skrining penyakit malaria di wilayah kerja Puskesmas Banyuasin Kecamatan Loano Kabupaten Purworejo Propinsi Jawa Tengah.

\section{METODE PENELITIAN}

Penelitian ini merupakan jenis penelitian deskriptif. Penelitian ini menggunakan uji validitas dengan mengukur sensitivitas dan spesifisitas gejala klinis malaria sebagai uji skrining. Standarisasi nilai validitas untuk uji skrining berdasarkan kriteria Dinkes ${ }^{5}$ untuk sensitivitas yaitu $85 \%$. Populasi pada penelitian ini adalah semua penduduk yang tinggal di wilayah kerja Puskesmas Banyuasin Kecamatan Loano Kabupaten Purworejo Propinsi Jawa Tengah. Sampel dalam penelitian ini adalah orang dengan gejala demam periodik, nyeri pada persendian dan mual dalam waktu 2 minggu terakhir, dengan kriteria inklusi: mengalami gejala demam periodik, nyeri pada persendian dan mual dalam waktu 2 minggu terakhir, tinggal di wilayah kerja Puskesmas Banyuasin, dan kriteria eksklusi: tidak bersedia dijadikan sampel penelitian. Besar sampel menggunakan rumus ${ }^{6}$ yang berjumlah 96 orang. Teknik pengambilan sampel secara consecutive sampling ${ }^{7}$.

Alat ukur yang digunakan dalam penelitian ini adalah kuesioner untuk pengumpulan data primer yaitu identitas responden dan gejala klinis malaria. Apabila subjek atau responden tergolong anak-anak maka wawancara dilakukan dengan orang tuanya. Pengambilan dan pemeriksaan sediaan darah untuk mengetahui adanya parasit melalui pemeriksaan mikroskopik dengan peralatan dan bahan meliputi : obyek gelas, box slide, blood lancet, kapas, alkohol 70\%, giemsa 5\% dan mikroskop binokuler. 


\section{HASIL PENELITIAN DAN PEMBAHASAN}

a. Karakteristik Responden Skrining

1) Distribusi Responden Skrining Berdasarkan Jenis Kelamin

Distribusi responden skrining berdasarkan jenis kelamin di wilayah kerja Puskesmas Banyuasin yaitu laki-laki berjumlah 49 orang (51\%) dan perempuan berjumlah 47 orang $(49 \%)$.

2) Distribusi responden skrining berdasarkan kelompok umur

Tabel 1. Distribusi Frekuensi Responden Skrining Berdasarkan Kelompok umur di Wilayah Kerja Puskesmas Banyuasin Kecamatan Loano Kabupaten Purworejo

\begin{tabular}{ccc}
\hline Kelompok Umur (tahun) & Jumlah & Persentase (\%) \\
\hline $2-10$ & 30 & 31,3 \\
\hline $11-20$ & 16 & 16,7 \\
\hline $21-30$ & 11 & 11,4 \\
\hline $31-40$ & 14 & 14,6 \\
\hline $41-60$ & 14 & 14,6 \\
\hline $61-70$ & 8 & 8,3 \\
\hline$\geq 75$ & 3 & 3,1 \\
\hline Total & 96 & 100 \\
\hline
\end{tabular}

Distribusi responden skrining berdasarkan kelompok umur di wilayah kerja Puskesmas Banyuasin yaitu umur termuda 2 tahun sedangkan umur tertua 85 tahun. Kelompok umur 2-10 tahun sebanyak 30 orang $(31,3 \%)$ merupakan kelompok umur terbanyak yang menjadi responden skrining.

3) Distribusi frekuensi berdasarkan gejala klinis malaria di wilayah kerja Puskesmas Banyuasin

Berdasarkan gejala klinis yang dirasakan oleh responden menunjukan bahwa gejala klinis tunggal merupakan gejala klinis yang paling banyak dirasakan yaitu demam (100\%), sakit kepala $(76 \%)$, nafsu makan berkurang $(65,6 \%)$, kedinginan $(61,4 \%)$ dan gejala klinis yang paling sedikit dirasakan adalah nyeri pada persendian (10,4\%), seperti ditunjukan pada Tabel 6 sebagai berikut : 
Tabel 2. Distribusi Frekuensi Responden Skrining Berdasarkan Gejala Klinis Malaria di Wilayah Kerja Puskesmas Banyuasin Kecamatan Loano Kabupaten Purworejo

\begin{tabular}{lcc}
\hline Gejala Klinis & Jumlah & $\begin{array}{c}\text { Persentase } \\
(\%)\end{array}$ \\
\hline Demam periodic & 96 & 100 \\
\hline Menggigil & 53 & 55,2 \\
\hline Kedinginan & 59 & 61,4 \\
\hline Sakit kepala & 73 & 76 \\
\hline Nyeri pada persendian & 10 & 10,4 \\
\hline Mual & 13 & 13,5 \\
\hline Muntah & 20 & 20,8 \\
\hline Nafsu makan berkurang & 63 & 65,6 \\
\hline Demam periodik+Nyeri pada persendian +Mual & 7 & 7,3 \\
\hline Lain-lain (batuk, pusing) & 17 & 17,7 \\
\hline
\end{tabular}

Penelitian ini hanya menggabungkan gejala klinis yang dirasakan oleh responden seperti demam periodik, nyeri pada persendian dan mual. Hasil penggabungan gejala demam periodik, nyeri pada persendian dan mual dirasakan oleh 7 responden $(7,3 \%)$. Ketiga gejala klinis tersebut kemudian akan dihitung nilai sensitivitas dan spesifisitas untuk dijadikan uji skrining.

4) Distribusi frekuensi gejala klinis malaria berdasarkan hasil pemeriksaan sediaan darah Positif Malaria di laboratorium Puskesmas Banyuasin

Berdasarkan hasil pemeriksaan sediaan darah di laboratorium Puskesmas Banyuasin menunjukan bahwa gejala klinis yang menunjukan hasil positif malaria paling tinggi adalah demam periodik (100\%), mual $(100 \%)$, nafsu makan berkurang $(66,7 \%)$ dan yang paling rendah adalah kedinginan $(33,3)$ dan sakit kepala $(33,3)$, sedangkan ketiga gejala klinis gabungan antara demam periodik, nyeri pada persendian dan mual $(58,3 \%)$.

Tabel 3. Distribusi Frekuensi Gejala Klinis Malaria Responden Skrining Berdasarkan Hasil Pemeriksaan Sediaan Darah di Laboratorium Puskesmas Banyuasin Kecamatan Loano Kabupaten Purworejo

\begin{tabular}{|c|c|c|}
\hline Gejala Klinis & Jumlah & Persentase (\%) \\
\hline Demam periodik & 12 & 100 \\
\hline Menggigil & 5 & 41,67 \\
\hline Kedinginan & 4 & 33,3 \\
\hline Sakit kepala & 4 & 33,3 \\
\hline Nyeri pada persendian & 7 & 58,3 \\
\hline Mual & 12 & 100 \\
\hline Muntah & 7 & 58,3 \\
\hline Nafsu makan berkurang & 8 & 66,7 \\
\hline Demam periodik+Nyeri pada persendian + Mual & 7 & 58,3 \\
\hline Lain-lain (batuk, pusing) & 2 & 16,7 \\
\hline
\end{tabular}


5) Distribusi frekuensi hasil pemeriksaan sediaan darah di laboratorium berdasarkan kelompok umur dan jenis kelamin di wilayah kerja Puskesmas Banyuasin

Hasil pemeriksaan sediaan darah di laboratorium menunjukan bahwa malaria paling banyak diderita pada kelompok umur $2-10$ tahun sebesar $75,1 \%$ (5 orang) dan terendah pada umur 11-20 tahun, 21-30 tahun dan 31-40 tahun dengan masing-masing sebesar $8,3 \%$, seperti ditunjukan pada tabel 8 dibawah ini:

Tabel 4. Distribusi Frekuensi Hasil Pemeriksaan Sediaan Darah di Laboratorium Berdasarkan Kelompok Umur dan Jenis Kelamin Puskesmas Banyuasin Kecamatan Loano Kabupaten Purworejo

\begin{tabular}{ccccccc}
\hline Umur (tahun) & Laki-Laki & Persentase (\%) & Perempuan & Persentase (\%) & Jumlah & Persentase (\%) \\
\hline $2-10$ & 5 & 41,7 & 4 & 33,4 & 9 & 75,1 \\
\hline $11-20$ & 1 & 8,3 & 0 & 0 & 1 & 8,3 \\
\hline $21-30$ & 0 & 0 & 1 & 8,3 & 1 & 8,3 \\
\hline $31-40$ & 1 & 8,3 & 0 & 0 & 1 & 8,3 \\
\hline $41-50$ & 0 & 0 & 0 & 0 & 0 & 0 \\
\hline $51-60$ & 0 & 0 & 0 & 0 & 0 & 0 \\
\hline $61-70$ & 0 & 0 & 0 & 0 & 0 & 0 \\
\hline$\geq 75$ & 0 & 0 & 0 & 0 & 0 & 0 \\
\hline Total & 7 & 58,3 & 5 & 41,7 & 12 & 100 \\
\hline
\end{tabular}

Tabel 4 menunjukan bahwa dari 96 responden yang positif malaria sebanyak 12 responden dan yang paling banyak menderita malaria adalah lakilaki yaitu 7 orang $(58,3 \%)$, dibanding jenis kelamin perempuan 5 orang $(41,7 \%)$. Dilihat dari kelompok umur maka yang paling banyak positif malaria adalah kelompok umur 2-10 tahun dengan jenis kelamin laki-laki $(41,7 \%)$.

Tabel 5. Distribusi Frekuensi Hasil Pemeriksaan Sediaan Darah Positif Berdasarkan Kelompok Umur di Wilayah Kerja Puskesmas Banyuasin Kecamatan Loano Kabupaten Purworejo

\begin{tabular}{ccccc}
\hline Umur (tahun) & Jumlah Sediaan Darah diperiksa & \multicolumn{3}{c}{ Sediaan Darah Persentase (\%) } \\
\cline { 3 - 4 } & & \multicolumn{2}{c}{ Positif } & \multirow{2}{*}{ Negatif } \\
\cline { 3 - 4 } & & 2 & 7 & 21 \\
\hline $2-10$ & 30 & 1 & 0 & 15 \\
\hline $11-20$ & 16 & 1 & 0 & 10 \\
\hline $21-30$ & 11 & 0 & 1 & 13 \\
\hline $31-40$ & 14 & 0 & 0 & 8 \\
\hline $41-50$ & 8 & 0 & 0 & 6 \\
\hline $51-60$ & 6 & 0 & 0 & 8 \\
\hline $61-70$ & 8 & 0 & 0 & 3 \\
\hline$\geq 75$ & 3 & 4 & 8 & 84 \\
\hline Total & 96 & & & \\
\hline
\end{tabular}

Tabel 5 menunjukan bahwa sediaan darah positif terbanyak ditemukan pada kelompok umur 2-10 tahun (9 orang) disusul kelompok umur 11-20 tahun, 
21-30 tahun dan 31-40 tahun. Proporsi Plasmodium dari seluruh sediaan darah positif adalah Plasmodium falciparum sebesar 33,3\% (4 orang) dan Plasmodium vivax sebesar $66,7 \%$ (8 orang).

b. Hasil analisis validitas uji skrining gejala klinis malaria terhadap pemeriksaan sediaan darah tepi secara mikroskopik (baku emas) dengan menghitung sensitivitas dan spesifisitas

Hasil analisis validitas dengan menggunakan tabel $2 \times 2$ bertujuan untuk melihat sensitivitas dan spesifisitas uji skrining gejala klinis malaria yaitu demam periodik, nyeri pada persendian dan mual yang dibandingkan dengan baku emas yaitu pemeriksaan sediaan darah tepi secara mikroskopik. Hasil analisis dapat dilihat pada tabel berikut :

Tabel 6. Nilai Validitas Hasil Uji Skrining Gejala Klinis Demam Periodik dengan Pemeriksaan Sediaan Darah Tepi Secara Mikroskopik Sebagai Baku Emas.

\begin{tabular}{ccccc}
\hline & \multicolumn{4}{c}{$\begin{array}{c}\text { Pemeriksaan SD tepi secara } \\
\text { mikroskopik }\end{array}$} \\
\cline { 2 - 4 } & & Positif $(+)$ & Negatif (-) & \\
\hline Demam periodik & Positif (+) & 12 & 0 & 12 \\
\cline { 2 - 5 } & Negatif (-) & 0 & 84 & 84 \\
\hline Sensitivitas (Se) & $=\mathrm{a} / \mathrm{a}+\mathrm{c} \times 100 \%$ & & \\
& $=12 / 12 \times 100 \%$ & & & \\
& $=100 \%$ & & & \\
Spesifisitas $(\mathrm{Sp})$ & $=\mathrm{d} / \mathrm{b}+\mathrm{d} \times 100 \%$ \\
& $=84 / 84 \times 100 \%$ \\
& $=100 \%$ & & & \\
& & & &
\end{tabular}

Tabel 7. Nilai Validitas Hasil Uji Skrining Gejala Klinis Nyeri Pada Persendian dengan Pemeriksaan Sediaan Darah Tepi Secara Mikroskopik Sebagai Baku Emas.

\begin{tabular}{lcccc}
\hline & & \multicolumn{3}{c}{$\begin{array}{c}\text { Pemeriksaan SD tepi secara } \\
\text { mikroskopik }\end{array}$} \\
\cline { 2 - 5 } & & Positif $(+)$ & Negatif $(-)$ & \\
\hline \multirow{2}{*}{ Nyeri pada persendian } & Positif $(+)$ & 7 & 3 & 10 \\
\cline { 2 - 5 } & Negatif $(-)$ & 5 & 81 & 86 \\
\hline & & 12 & 84 & 96 \\
\hline
\end{tabular}

\footnotetext{
Sensitivitas $(\mathrm{Se})=\mathrm{a} / \mathrm{a}+\mathrm{c} \times 100 \%$

$=7 / 12 \times 100 \%$

$=58,3 \%$

Spesifisitas $(S p)=d / b+d \times 100 \%$

$=81 / 84 \times 100 \%$

$=96,4 \%$
} 
Tabel 8. Nilai Validitas Hasil Uji Skrining Gejala Klinis Mual dengan Pemeriksaan Sediaan Darah Tepi Secara Mikroskopik Sebagai Baku Emas.

\begin{tabular}{|c|c|c|c|c|}
\hline & & \multicolumn{2}{|c|}{$\begin{array}{l}\text { Pemeriksaan SD tepi secara } \\
\text { mikroskopik }\end{array}$} & \\
\hline & & Positif (+) & Negatif (-) & \\
\hline \multirow[t]{3}{*}{ Mual } & Positif (+) & 12 & 1 & 13 \\
\hline & Negatif (-) & 0 & 83 & 83 \\
\hline & & 12 & 84 & 96 \\
\hline $\begin{array}{l}\text { Sensitivitas (Se) } \\
\text { Spesifisitas (Sp) }\end{array}$ & $\begin{array}{l}=a / a+c \times 100 \% \\
=12 / 12 \times 100 \% \\
=100 \% \\
=d / b+d \times 100 \% \\
=83 / 84 \times 100 \% \\
=98,8 \%\end{array}$ & & & \\
\hline
\end{tabular}

Tabel 9. Nilai Validitas Hasil Uji Skrining Gejala Klinis Demam Periodik+ Mual dengan Pemeriksaan Sediaan Darah Tepi Secara Mikroskopik Sebagai Baku Emas.

\begin{tabular}{lcccc}
\hline & & \multicolumn{3}{c}{$\begin{array}{c}\text { Pemeriksaan SD tepi secara } \\
\text { mikroskopik }\end{array}$} \\
\cline { 2 - 4 } & & Positif $(+)$ & Negatif (-) & \\
\hline Demam periodik + mual & Positif $(+)$ & 12 & 1 & 13 \\
\hline & Negatif $(-)$ & 0 & 83 & 83 \\
\hline & & 12 & 84 & 96 \\
\hline
\end{tabular}
Sensitivitas (Se) $=\mathrm{a} / \mathrm{a}+\mathrm{c} \times 100 \%$
$=12 / 12 \times 100 \%$
$=100 \%$
Spesifisitas $(S p)=d / b+d \times 100 \%$
$=83 / 84 \times 100 \%$
$=98,8 \%$

Tabel 10. Nilai Validitas Hasil Uji Skrining Gejala Klinis Demam Periodik+ Nyeri Pada Persendian dengan Pemeriksaan Sediaan Darah Tepi Secara Mikroskopik Sebagai Baku Emas.

\begin{tabular}{|c|c|c|c|c|}
\hline & & \multicolumn{2}{|c|}{$\begin{array}{l}\text { Pemeriksaan SD tepi secara } \\
\text { mikroskopik }\end{array}$} & \\
\hline & & Positif $(+)$ & Negatif (-) & \\
\hline \multirow{3}{*}{$\begin{array}{l}\text { Demam periodik + nyeri } \\
\text { pada persendian }\end{array}$} & Positif (+) & 7 & 3 & 10 \\
\hline & Negatif (-) & 5 & 81 & 86 \\
\hline & & 12 & 84 & 96 \\
\hline \multicolumn{5}{|c|}{$\begin{aligned} \text { Sensitivitas }(\mathrm{Se}) & =\mathrm{a} / \mathrm{a}+\mathrm{c} \times 100 \% \\
& =7 / 12 \times 100 \% \\
& =58,3 \% \\
\text { Spesifisitas }(\mathrm{Sp}) & =\mathrm{d} / \mathrm{b}+\mathrm{d} \times 100 \% \\
& =81 / 84 \times 100 \% \\
& =96,4 \%\end{aligned}$} \\
\hline
\end{tabular}


Tabel 11. Nilai Validitas Hasil Uji Skrining Gejala Klinis Nyeri Pada Persendian+Mual dengan Pemeriksaan Sediaan Darah Tepi Secara Mikroskopik Sebagai Baku Emas.

\begin{tabular}{|c|c|c|c|c|}
\hline & & \multicolumn{2}{|c|}{$\begin{array}{c}\text { Pemeriksaan SD tepi secara } \\
\text { mikroskopik }\end{array}$} & \\
\hline & & Positif (+) & Negatif (-) & \\
\hline \multirow{3}{*}{$\begin{array}{c}\text { Nyeri pada } \\
\text { persendian + mual }\end{array}$} & Positif (+) & 7 & 0 & 7 \\
\hline & Negatif (-) & 5 & 84 & 89 \\
\hline & & 12 & 84 & 96 \\
\hline \multicolumn{5}{|c|}{$\begin{aligned} \text { Sensitivitas }(\mathrm{Se}) & =\mathrm{a} / \mathrm{a}+\mathrm{c} \times 100 \% \\
& =7 / 12 \times 100 \% \\
& =58,3 \% \\
\text { Spesifisitas }(\mathrm{Sp}) & =\mathrm{d} / \mathrm{b}+\mathrm{d} \times 100 \% \\
& =84 / 84 \times 100 \% \\
& =100 \%\end{aligned}$} \\
\hline
\end{tabular}

Tabel 12. Nilai Validitas Hasil Uji Skrining Gejala Klinis Demam Periodik+ Nyeri Pada Persendian+Mual dengan Pemeriksaan Sediaan Darah Tepi Secara Mikroskopik Sebagai Baku Emas.

Pemeriksaan SD tepi

secara mikroskopik

\begin{tabular}{|c|c|c|c|c|}
\hline & & & \\
\hline & & Positif $(+)$ & Negatif (-) & \\
\hline \multirow{3}{*}{$\begin{array}{l}\text { Demam periodik + } \\
\text { nyeri pada } \\
\text { persendian }+ \text { mual }\end{array}$} & Positif (+) & 7 & 0 & 7 \\
\hline & Negatif (-) & 5 & 84 & 89 \\
\hline & & 12 & 84 & 96 \\
\hline
\end{tabular}

Sensitivitas (Se) $=a / a+c \times 100 \%$

$=7 / 12 \times 100 \%$

$=58,3 \%$

Spesifisitas (Sp) $=\mathrm{d} / \mathrm{b}+\mathrm{d} \times 100 \%$

$=84 / 84 \times 100 \%$

$=100 \%$

\section{c. Pembahasan}

Pelaksanaan skrining malaria menggunakan kriteria skrining yaitu demam periodik, nyeri pada persendian dan mual (muncul bersamaan) dalam waktu dua minggu terakhir dengan tujuan memisahkan mereka yang sehat terhadap mereka yang kemungkinan besar menderita malaria pada masyarakat sehingga dapat cepat dilakukan pengobatan. Penyakit malaria dapat dicegah sedini mungkin serta mencegah terjadinya penularan di masyarakat.

Secara keseluruhan pada pelaksanaan skrining ditemukan 174 orang yang diduga mengalami gejala klinis malaria kemudian diambil 96 orang yang memenuhi kriteria inklusi untuk dijadikan sampel penelitian. Sebanyak 78 orang tidak memenuhi kriteria inklusi karena hanya mengalami gejala klinis tunggal (demam periodik atau nyeri pada persendian atau mual), gejala sudah dirasakan melebihi 2 minggu dan bertempat tinggal diluar wilayah kerja Puskesmas Banyuasin.

Berdasarkan pada perhitungan validitas uji skrining gejala klinis malaria, nilai sensitivitas dan spesifisitas gejala klinis tunggal yang paling baik untuk memisahkan antara individu yang menderita malaria dan yang sehat adalah demam periodik (sensitivitas $100 \%$ dan spesifisitas 100\%) dan mual (sensitivitas 100\% dan spesifisitas $98,8 \%$ ). Gejala nyeri pada persendian mempunyai nilai sensitivitas 
$58,3 \%$ dan spesifisitas $96,4 \%$. Tes atau uji skrining dilakukan untuk menemukan kasus agar mendapatkan perawatan dan pengobatan, maka dengan tes sensitivitas yang lebih tepat digunakan tanpa memperhatikan nilai spesifisitas dari tes atau uji skrining tersebut ${ }^{8}$.

Masing-masing gejala klinis tunggal dihitung sensitivitas dan spesifisitasnya, maka selanjutnya menghitung gejala klinis yang dikombinasi untuk dijadikan uji skrining. Nilai validitas hasil uji skrining gejala klinis demam periodik+mual dengan pemeriksaan sediaan darah tepi secara mikroskopik sebagai baku emas memiliki sensitivitas $100 \%$ dan spesifisitas $98,8 \%$. Nilai validitas hasil uji skrining gejala klinis demam periodik+nyeri pada persendian dengan pemeriksaan sediaan darah tepi secara mikroskopik bebagai baku emas memiliki sensitivitas $58,3 \%$ dan spesifisitas $96,4 \%$. Nilai validitas hasil uji skrining gejala klinis nyeri pada persendian+ mual dengan pemeriksaan sediaan darah tepi secara mikroskopik bebagai baku emas memiliki sensitivitas $58,3 \%$ dan spesifisitas $100 \%$.

Nilai validitas hasil uji skrining gejala klinis demam periodik+nyeri pada persendian+mual dengan pemeriksaan sediaan darah tepi secara mikroskopik bebagai baku emas memiliki sensitivitas $58,3 \%$ dan spesifisitas $100 \%$. Hal ini berarti gejala kombinasi demam deriodik+nyeri pada persendian+mual tidak dapat digunakan sebagai uji skrining malaria karena hanya memiliki sensitivitas $58,3 \%$ dan spesifisitas $100 \%$. Rendahnya sensitivitas disebabkan karena kebanyakan responden yang positif malaria terdapat pada kelompok umur $2-10$ tahun $(75,1 \%)$, sehingga peneliti tidak dapat menggali informasi terutama mengenai gejala nyeri pada persendian.

Penelitian yang dilakukan oleh Sulistiyowati ${ }^{9}$ dengan gejala klinis yang berbeda dengan peneliti yaitu demam memiliki sensitifitas $100 \%$ dan spesifisitas $79 \%$, sakit kepala memiliki sensitifitas $48,38 \%$ dan spesifisitas $99,19 \%$, menggigil/ kedinginan memiliki sensitivitas $90,32 \%$, serta gejala kombinasi panas+sakit kepala memiliki sensitivitas $45,16 \%$ dan spesifisitas $100 \%$, panas+menggigil/kedinginan memiliki sensitivitas $93,53 \%$ dan spesifisitas $98,38 \%$, menggigil/kedingnan+sakit kepala memiliki sensitivitas $29 \%$ dan spesifisitas $100 \%$ dan demam+menggigil+sakit kepala memiliki sensitivitas $74,19 \%$ dan spesifisitas $93,54 \%$ dan dikatakan dapat digunakan sebagai uji skrining di masyarakat akan tetapi bila dibandingkan dengan baku emas yaitu pemeriksaan sediaan darah secara mikroskopis, ketiga gejala tersebut belum memenuhi nilai standar untuk dijadikan uji skrining (nilai standarisasi sensitivitas uji skrining berdasarkan kriteria Dinkes ${ }^{5}$ yaitu $85 \%$.

Berdasarkan hasil perhitungan validitas dari gejala tunggal demam periodik memiliki sensitivitas $100 \%$ dan mual sensitivitas $100 \%$, begitupun apabila gejala tersebut dikombinasikan yaitu demam periodik+mual memiliki sensitivitas $100 \%$ dan spesifisitas $98,8 \%$. Dengan demikian gejala kombinasi demam periodik+mual dapat dijadikan uji skrining malaria berdasarkan gejala klinis di masyarakat karena memiliki sensitivitas yang sangat tinggi yaitu 100\% dibandingkan dengan gejala klinis yang digunakan oleh sulistyowati yaitu demam/panas+menggigil/kedinginan yang memiliki nilai sensitivitas $93,53 \%$.

\section{SIMPULAN DAN SARAN}

\section{a. Simpulan}

Berdasarkan hasil analisis dan pembahasan mengenai skrining malaria di wilayah kerja Puskesmas Banyuasin Kecamatan Loano Kabupaten Purworejo Propinsi Jawa Tengah maka dapat disimpulkan bahwa : 
1) Sensitivitas dari gejala klinis yang dijadikan uji skrining yaitu demam periodik memiliki sensitivitas $100 \%$, nyeri pada persendian memiliki sensitivitas $58,3 \%$ dan mual memiliki sensitivitas $100 \%$.

2) Spesifisitas dari gejala klinis yang dijadikan uji skrining yaitu periodik memiliki spesifisitas $100 \%$, nyeri pada persendian memiliki spesifisitas $96,4 \%$ dan mual memiliki spesifistas $98,8 \%$.

3) Sensitivitas dan spesifisitas dari hasil kombinasi ketiga gejala yaitu demam periodik+nyeri pada persendian+mual memiliki sensitivitas $58,3 \%$ dan spesifisitas $100 \%$, hal ini berarti ketiga gejala kombinasi tersebut tidak dapat digunakan sebagai uji skrining malaria karena memiliki sensitivitas yang rendah.

4) Karakteristik gejala klinis malaria pada masyarakat yang diduga malaria dan terbukti memiliki sensitivitas dan spesifisitas tinggi dibandingkan dengan pemeriksaan sediaan darah tepi secara mikroskopis dan dapat digunakan sebagai uji skrining di wilayah kerja Puskesmas Banyuasin adalah yaitu gejala demam periodik dan mual, serta kombinasi kedua gejala tersebut yaitu demam periodik+mual yang memiliki sensitivitas $100 \%$ dan spesifisitas $98,8 \%$.

\section{b. Saran}

Saran yang dapat dipertimbangkan dan diharapkan bermanfaat untuk penetapan malaria berdasarkan gejala klinis yang dijadikan uji skrining pada masyarakat di wilayah kerja Puskesmas Banyuasin Kecamatan Loano Kabupaten Purworejo Propisi Jawa Tengah, yaitu :

1) Gejala demam periodik dan kombinasi gejala klinis demam periodik+ mual dapat dijadikan uji skrining untuk menjaring penderita malaria di wilayah kerja Puskesmas Banyuasin. Dengan demikian penderita dapat segera diberikan pengobatan dan tidak menjadi sumber penularan.

2) Untuk menekan terjadinya transmisi kasus malaria, maka perlu dilakukan penemuan kasus secara dini baik secara aktif maupun pasif salah satunya yaitu dengan menggunakan uji skrining.

3) Kombinasi gejala klinis demam periodik+nyeri pada persendian+mual dapat dijadikan uji diagnostik untuk malaria klinis.

4) Kepada peneliti selanjutnya yang ingin melakukan penelitian yang sama maka sebaiknya mengambil responden penderita malaria yang usia dewasa $(\geq 10$ tahun keatas) sehingga ada komunikasi timbal balik.

\section{DAFTAR PUSTAKA}

1. World Health Organization. Malaria, Global and Regional Risk, www.who.int/ countries, Geneva, Diambil pada tanggal 28 Maret 2008, Yogyakarta.2004

2. Departemen Kesehatan RI. .Presiden Hadiri Peringatan Hari Malaria Sedunia Ke-1 dan Resmikan Gedung Rawat Inap Terpadu RSCM, www.depkes.go.id, Diambil pada tanggal 14 Mei 2008, Yogyakarta.2008

3. Dinas Kesehatan Kabupaten Purworejo Propinsi Jawa Tengah.Laporan Tahunan Penemuan Penderita Malaria, Kabupaten Purworejo, Propinsi Jawa Tengah. 2008,

4. Anomim. Data Pemberantasan Penyakit (P2) Malaria UPTD Puskesmas Banyuasin. Puskesmas Banyuasin Kecamatan Loano Kabupaten Puworejo, Propinsi Jawa Tengah.2008

5. Dinas Kesehatan Propinsi D.I Yogyakarta. Nilai Standarisasi Validitas uji Skrining, D. I Yogyakarta.2007

6. Kuntara, Suwanto. Penentuan Besar Sampel. Jurnal Kedokteran dan Farmasi Medika, XXIX (10): 795-800. 2003 
7. Sastroasmoro, S. Dasar-Dasar Metodologi penelitian Klinis, Edisi 2, Sagung Seto, Jakarta. 2002

8. Sutrisna, B. Pengantar Metode Epidemiologi, Edisi 2, Dian Rakyat, Jakarta. 1996

9. Sulistyowati. Skrining Malaria di Kecamatan Turi, tahun 2002. Jurnal Kedokteran dan Kesehatan Medika, XXXII (32): 17-22. 2006 